\title{
sciendo \\ COMPARING MONEY AND TIME DONATION: WHAT DO EXPERIMENTS TELL US?
}

\author{
PORÓWNANIE DAROWIZN PIENIĘŻNYCH I CZASU: \\ CO MÓWIA BADANIA EKSPERYMENTALNE?
}

\author{
Tingting He \\ Division of Management, Marketing and Entrepreneurship, College of Business, Governors State University \\ 1 University Pkwy, University Park, IL 60484, USA \\ the@govst.edu ORCID 0000-0003-1679-9956 \\ DOl: 10.2478/minib-2021-0015
}

\section{ABSTRACT}

Money donation and time donation, as charitable donations from individuals to organizations, are two forms of prosocial behavior that have been increasingly studied in recent years. Despite the vast amount of research about money and/or time donation, however, only limited work has been done on reviewing the research on these two forms of charitable donations as comparable or parallel entities. In this paper, we seek to help fill this gap by reviewing the existing research. We applied the backwards and forwards snowballing technique to arrive at a review sample of 39 experimental papers published in 2000-2020 that have compared money and time donation, or at least analyzed them as two parallel entities. We examine the issues that are predominantly considered in these experimental papers and summarize the general directions of their findings. We also point out certain gaps in the existing literature and posit some potentially fruitful directions for future experimental research regarding money and time donation.

Key words: Money donation, Time donation, Prosocial behavior, Charitable donations 


\section{ABSTRAKT}

Darowizny charytatywne od osób indywidualnych na rzecz organizacji charytatywnej często przybierają formę darowizn pieniężnych lub darowizna czasu. Te dwie formy zachowań prospołecznych są coraz częściej badane w ostatnich latach. Jednak pomimo dużej ilości isniejących badań nad darowiznami pieniędzy lub czasu, do tej pory tylko ograniczone badania przeglądowe zostały poświęcone obydwu tym formom darowizn charytatywnych postrzeganym jako zjawiskom porównywalnym lub równoległym. Celem niniejszego artykułu było wypełnienie tej luki. Techniką snowballing wybrano próbę badawczą 39 prac eksperymentalnych opublikowanych w latach 2000-2020, które porównywały darowizny pieniężne i czasowe lub przynajmniej analizowały je jako dwie równoległe zjawiska. Prace te analizowano pod kątem tego, które kwestie badawcze były najczęściej w nich rozważane. Podsumowano ogólne kierunki ich ustaleń. Wskazano na pewne luki w istniejącej literaturze i zaproponowano kilka potencjalnie owocnych kierunków dla przyszłych badań eksperymentalnych dotyczących darowizn pieniędzy i czasu.

Słowa kluczowe: darowizny pieniężne, poświęcenie czasu, zachowanie prospołeczne, darowizny charytatywne

JEL: M31

\section{Introduction}

Prosocial behavior, including the making of charitable donations, has emerged as a subject of great interest in recent years (Marti-Vilar, Serrano-Pastor, and Sala, 2019; Tiltay and Torlak, 2020). Prosocial behavior offers a powerful source of health and happiness for individual consumers, as well as funding and help to charitable organizations (Gertler, 2015; Jones, 2006). Prosocial behavior may increase people's perceptions of meaning in life, sense of self-worth and social connection (Klein, 2017). It is clearly, therefore, a meaningful field of further research. Prosocial behavior includes different perspectives: for instance, donating is often different from helping (Kou, Konrath and Goldstein, 
2019; Tiltay and Torlak, 2020), and donating to a charitable organization is different from donating to a specific person, and even different from donating to a group of individuals (Ein-Gar and Levontin, 2013).

Among these different forms of prosocial behavior, donations from individuals to charitable organizations, or "charitable donations" as we will call them, have been significant in both developed regions (Devlin and Zhao, 2017; Bauer, Bredtmann and Schmidt, 2013; Berger, 2006) and developing societies (Diop, Johnston, et al. 2018; Nelson, Schluter and Vance, 2018). They may generate impacts to both religious (Borgonovi, 2008) and secular communities (Choi and DiNitto, 2012), and to both young (Ottoni-Wilhelm, Estell and Perdue, 2014) and aged individuals (Choi and Kim, 2011). Charitable donations are also important forms of civic engagement (Jones, 2006) and they may give rise to social change (Wong, Ong and Zheng, 2017).

In this paper, we focus on charitable donations in the form of donations of money and of time. There are different forms of charitable donations; donating money and donating time are two different forms (Tiltay and Torlak, 2020), whereas donating blood is a third form of donation that is sometimes analyzed along with the first two (Studte, Clement, et al. 2019). Perhaps because people often think of donations of money and donations of time as the major forms of donations to charitable organizations, they are often estimated together (Bekkers, 2010; Feldman, 2010). To know the similarities and differences between money and time donation, it is essential to know papers that analyze both of them. Despite the vast amount of research on charitable donations in general (Wiepking and Bekkers, 2012; Bekkers and Wiepking, 2011), review research comparing money donation and time donation from individuals to charitable organizations is scarce. Most often, review research either focuses on money donation (Wiepking and Bekkers, 2012; Bekkers and Wiepking, 2011; Bekkers and Wiepking, 2010) or on time donation (Bekkers, van Ingen, et al. 2016), while research that focuses on reviewing money donation and time donation parallelly is either relatively brief (Monga and Zor, 2019; Hill, 2012) or limited in scope (Wong, Ong and Zheng, 2017; Feeley, Anker and Aloe, 2012). Since considerations of money and time are psychologically distinct notions (MacDonnell and White, 2015), filling this 
gap with more review research about them may help us understand them better. Therefore, in this paper we focus on two types of charitable donations (i.e. donations from individuals to charitable organizations): comparing money donations to time donations.

Research into prosocial behavior may follow different methodologies, such as experimental research (e.g. Kandaurova and Lee, 2019; MacDonnell and White, K, 2015; Liu and Aaker, 2008), empirical research with secondary data (e.g. Faulkner and Romaniuk, 2019; Goktas, Erol, et al. 2019; Forbes and Zampelli, 2011), theory modeling (e.g. Apinunmahakul and Devlin, 2008; Handy and Katz, 2008; Smith and Chang, 2002), and conceptual modeling (e.g. Kim, 2014; Mason, 2013; Lyons, McGregor-Lowndes and O'Donoghue, 2006), etc. Since money and time have different psychological properties (Reed, et al. 2016), and there are significant psychological differences between money and time (Kim, 2014), it is important to investigate money and time donation with a methodology good for analyzing psychological properties and differences. In this paper, therefore, we focus on experimental research about money and time donation. Experimental research is good for analyzing human behavior (Reed, et al. 2016) and exploring social benefits in addition to self-interest behavior (Nelson, Schluter and Vance, 2018). Therefore, it is meaningful to particularly summarize and review experimental research about money and time donation. Moreover, since there is vast amount of research about money and time donation, it is more manageable in one paper to focus on a single important field.

The rest of this paper is organized as follows: We first describe the methodology used, then the results with the summarization and detailed explanations of the experimental literature collected, with the insights drawn from that. Then we have the conclusions, discussion, and future research, which are generated from the insights of the literature.

\section{Methodology}

To ensure that our review covered a sufficient number of papers, we used the snowballing method (Wohlin, 2014) to form our sample of papers. Snowballing is a technique that has been widely used for systematic 
literature reviews in social science (Browne, 2005). It allows researchers, through an iterative literature search, to collect a sample of literature for synthesizing evidence and joint understanding of the status of a research area (Wohlin, 2014; Biernacki and Waldorf, 1981). For snowball sampling, it is important to construct a good start set that is neither too small nor too large, and covers different publishers, years, authors and communities (Wohlin, 2014). To ensure this, as our start set we retrieved articles from a cross-disciplinary database, the Web of Science Core Collection. Through the Web of Science database, we searched for all the articles in English in the years 2000 to 2020 in all the 8 citation indexes in the Web of Science Core Collection, to ensure recency and sufficiency of our review.

As mentioned earlier, our focus is on money donations and time donations made by individuals to charitable organizations. There are many different terms for such donations, to ensure our review included all the potentially relevant papers, instead of only searching for "money donation" and "time donation", we started our search with some general keywords that often appeared in the existing literature about charitable donations (Bekkers and Wiepking, 2010): Donations, philanthropy, charitable giving, charitable behavio(u)r, altruism, helping and prosocial behavio(u)r. We started by searching for any paper in the Web of Science Core Collection database with any of those keywords in the Topic, which includes title, abstract and keywords. This search found 721 papers. To ensure accurate and sufficient inclusion of all the relevant papers, we did manual filtering instead of screening by journal rankings (Zupic and Cater, 2015). To ensure inclusion of all useful papers, we included any paper that analyzes money and time donation in parallel, including papers that compare them.

We then checked those papers, following the procedure suggested by Wohlin (2014). We first read the title and abstract of each paper, and if we still could not decide then we read the full text. This way we screened out 73 papers as our start set - papers aiming to compare money donation and time donation or analyze money donation and time donation as two parallel entities. Then, following the snowball sampling procedure (Biernacki and Waldorf, 1981; Roetzel, 2019), we conducted multiple rounds of interactions of backward snowballing and forward snowballing, until no new paper could be located (Wohlin, 2014). When we performed 
such inerations, we read the introduction, literature review, conclusion and discussion, references, and forward citations of each paper, so as to identify all the potentially useful papers.

To ensure the quality of our review study, we only considered papers published in academic journals. Ultimately, as a result of the iterations of snowballing sampling, our sample of papers for review included 133 papers.

Even though we focus on experimental research in this paper, to ensure we include all the papers that fit our research requirements, during the process of snowballing, we included papers of any methodology in our pool, not just experimental. That is because non-experimental papers often quote and are quoted by papers that are experimental, so including papers applying any methodology ensured the completeness of our snowballing search process.

After the snowballing process, then we picked out of the final pool all the papers that are experimental. Among the 133 papers in the snowballing pool, 39 papers (or $31.11 \%$ ) made use of experiments. These 39 experimental papers were then taken as the sample for the present review study (these 39 papers are referred to herein as the "review sample").

\section{Results}

Using the R3.6.3 software package for bibliometric analysis (Sun et al. 2014), which is widely used in science and business studies (Roetzel, 2019; Schaltegger, Gibassier and Zvezdov, 2013), we plotted out the degree of productivity of papers in the sample by years as in Table 1 below.

Table 1 shows that the experimental research about both money and time donation has been increasing over the years. We also found the most relevant sources of the research works as below, ranked by the number of articles in each source: 
Table 1. Number of experimental papers produced in each given year dealing with both money and time donation

\begin{tabular}{c|c|c|c|c|c|c|c|c|c|c|c}
\hline Year & 2000 & 2001 & 2002 & 2003 & 2004 & 2005 & 2006 & 2007 & 2008 & 2009 & 2010 \\
\hline Articles & 0 & 0 & 0 & 1 & 0 & 0 & 0 & 2 & 1 & 1 & 1 \\
\hline Year & 2011 & 2012 & 2013 & 2014 & 2015 & 2016 & 2017 & 2018 & 2019 & 2020 & \\
\hline Articles & 1 & 4 & 2 & 4 & 1 & 4 & 2 & 4 & 5 & 6 & \\
\hline
\end{tabular}

Source: original table based on the papers in the review sample.

Table 2. The academic journals producing the highest number of experimental papers dealing with both money and time donation

\begin{tabular}{l|c|c}
\hline Rank & Source & Articles \\
\hline 1 & Journal of Consumer Research & 3 \\
2 & Psychological Science & 3 \\
3 & Innovative Higher Education & 2 \\
4 & Journal of Business Research & 2 \\
5 & Journal of Consumer Psychology & 2 \\
6 & Journal of Marketing & 2 \\
7 & Personality and Social Psychology Bulletin & 2 \\
8 & Sustainability & 2 \\
\hline
\end{tabular}

Source: original table based on the papers in the review sample.

The publications appeared in both journals of business research in general, and in journals specifically devoted to research about nonprofit organizations. We also generated a conceptual structure map and topic dendrogram for the papers as below. In the experimental papers in the output pool of our search, the dominant topic is what influences money 
and time donation - although we did notice other topics, such as how money donation and time donation influence the donors. Table 3 summarizes the major topics of those papers ${ }^{1}$.

Figure 1. Topic Dendrogram for the papers in the review sample

Topic Dendrogram

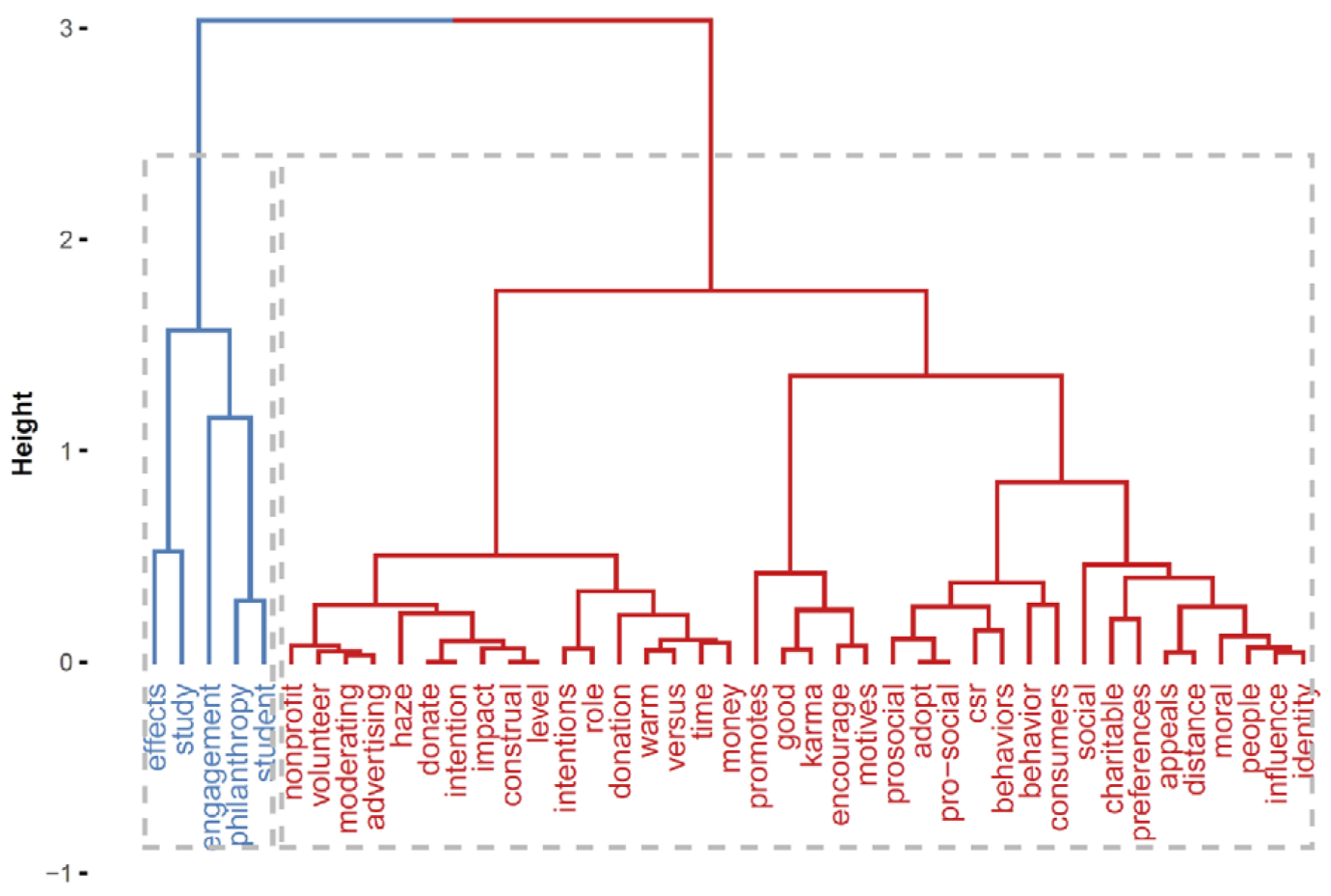

Source: original figure based on the papers in the review sample. 
Table 3. The major topics addressed by the papers in the review sample

\begin{tabular}{l|c}
\multicolumn{1}{c|}{ Topics } & No. Papers \\
\hline What influences money donation and time donation & 36 \\
Psychological factors & 24 \\
Motivators & 4 \\
Appeals & 2 \\
Temporal distance and construal level & 6 \\
Moral identity & 3 \\
Other factors (internal) & 5 \\
Other factors (external) & 7 \\
Preferences about money and time donations & 4 \\
Money and time donation: Complements or substitutes & 2 \\
Philanthropy education & 6 \\
CSR (Corporate social responsibility) & 3 \\
Judgments about money donation and time donation & 2 \\
Predictors of money donation and time donation & 1 \\
Scale for the intentions of money donation and time donation & 1 \\
\hline
\end{tabular}

Source: original table based on the papers in the review sample.

\section{The Psychological Factors}

Most of the papers are about psychological factors that influence money and time donation. There are 24 papers in this category. Most of those 24 papers use lab-based experiments, but some also use other methods, e.g. field experiments (Yeomans and Al-Ubaydli, 2018), scenario studies (Bekkers, 2010), etc. One noticeable phenomenon among those papers is that they have various ways of analyzing money and time donation in terms of intention and/or behavior, with some papers analyzing intention only, some behavior only, some both money and time donation, some intention of money donation and behavior of time donation, etc. For the sake of simplicity of the tables, therefore, we first summarize the intentions and behaviors in Table 4. Here, "Intention Only" means a paper only analyzes the intention, which may be the intention for "Money Donation" or "Time Donation"; and similar for "Behavior Only". "Both Intention and Behavior" means a paper analyzes both intention 
and behavior, which may be for money donation and/or for time donation. As is evident, only a few papers analyze both intention and behavior.

\section{Table 4. Classification of papers in the review sample by whether they address money/time donation, intention/behavior}

\begin{tabular}{|c|c|c|}
\hline Money Donation & Intention Only & Behavior Only \\
\hline References & $\begin{array}{l}\text { Madurapperuma and Kim (2020) } \\
\text { Kandaurova and Lee (2019) } \\
\text { Song and Kim (2019) } \\
\text { Zhang, Lin and Yang (2019) } \\
\text { Kulow and Kramer (2016) } \\
\text { Bischoff and Hansen (2016) } \\
\text { Kim (2014) } \\
\text { Michel and Rieunier (2012) } \\
\text { Pavey, Greitemeyer and Sparks (2011) } \\
\text { Bekkers (2010)Wheeler (2009) }\end{array}$ & $\begin{array}{l}\text { Williams (2019) } \\
\text { Lin and Reich (2018) } \\
\text { Nelson, Schluter and Vance (2018) } \\
\text { Yeomans and Al-Ubaydli (2018) } \\
\text { Brown, Meer and Konrath, Ho and Zarins (2016) } \\
\text { Lilley and Slonim (2014) } \\
\text { Winterich, Mittal and Aquino (2013) } \\
\text { Converse, Risen and Carter (2012) } \\
\text { Grant and Dutton (2012) } \\
\text { Liu and Aaker (2008) } \\
\text { Simmons and Emanuele (2004) }\end{array}$ \\
\hline Time Donation & Intention Only & Behavior Only \\
\hline References & $\begin{array}{l}\text { Karatas and Gurhan-Canli (2020) } \\
\text { Madurapperuma and Kim (2020) } \\
\text { Kandaurova and Lee (2019) } \\
\text { Song and Kim (2019) } \\
\text { Zhang, Lin and Yang (2019) } \\
\text { Bischoff and Hansen (2016) } \\
\text { Kim (2014) } \\
\text { Ein-Gar and Levontin (2013) } \\
\text { Michel and Rieunier (2012) } \\
\text { Pavey, Greitemeyer and Sparks (2011) } \\
\text { Bekkers (2010) } \\
\text { Wheeler (2009) }\end{array}$ & $\begin{array}{l}\text { Brown, Meer and Williams (2019) } \\
\text { Lin and Reich (2018) } \\
\text { Nelson, Schluter and Vance (2018) } \\
\text { Yeomans and Al-Ubaydli (2018) } \\
\text { Konrath, Ho and Zarins (2016) } \\
\text { Kulow and Kramer (2016) } \\
\text { Reed, Kay, et al. (2016) } \\
\text { Lilley and Slonim (2014) } \\
\text { Winterich, Mittal and Aquino (2013) } \\
\text { Converse, Risen and Carter (2012) } \\
\text { Grant and Dutton (2012) } \\
\text { Simmons and Emanuele (2004) }\end{array}$ \\
\hline Money Donation & Both Intention and Behavior & \\
\hline References & $\begin{array}{l}\text { Li, et al. (2020)Reed, Kay, et al. (2016) } \\
\text { MacDonnell and White (2015) } \\
\text { Ein-Gar and Levontin (2013) }\end{array}$ & \\
\hline Time Donation & Both Intention and Behavior & \\
\hline References & $\begin{array}{l}\text { Li, et al. } 2020 \\
\text { MacDonnell and White, } 2015 \\
\text { Liu and Aaker, } 2008\end{array}$ & \\
\hline
\end{tabular}

Source: original table based on the papers in the review sample. 
Now let us summarize more details of the papers in the review sample. In Table 5, as in Table 6 to Table 10 later on, "Factors" refer to the most notable factor(s) that impact money and time donations in the papers, "Moderators/Mediators" refer to the notable moderators and/or mediators, and "Effects on Money Donation and Time Donation Intention/Behavior" refer to the effects of the factors (with moderators and/or mediators) on money donation and time donation. As Table 5 shows, the first theme about the psychological factors relates to the motivation for prosocial behavior. Belief in karma (Kulow and Kramer, 2016; Converse, Risen and Carter, 2012) and warm glow (Lilley and Slonim, 2014) are two significant motivators. Lilley and Slonim (2014) argue that pure altruism and impure altruism (warm glow) are separable, with money donation being more due to pure altruism and time donation more due to warm glow. Moreover, Brown, Meer and Williams (2019) investigate warm glow as a factor that may influence the preference between money donation and time donation - a paper we will summarize in Table 11 as well.

\section{Table 5. Psychological Factors: Motivation}

\begin{tabular}{l|l|l|l}
\hline \multicolumn{1}{c|}{ Factors } & \multicolumn{1}{c|}{$\begin{array}{c}\text { Moderators/ } \\
\text { Mediators }\end{array}$} & $\begin{array}{c}\text { Effects on Money Donation and Time } \\
\text { Donation Intention/Behavior }\end{array}$ & References \\
\hline Belief in karma & $\begin{array}{l}\text { Personal control } \\
\text { over the external } \\
\text { environment }\end{array}$ & $\begin{array}{l}\text { Money and Time: When personal control of the } \\
\text { outcome is weak, + due to belief in karma }\end{array}$ & $\begin{array}{l}\text { Converse, } \\
\text { Risen and } \\
\text { Carter (2012) }\end{array}$ \\
\hline Belief in karma & $\begin{array}{l}\text { Charitable appeals } \\
\text { (other-gain } \\
\text { vs. self-gain) }\end{array}$ & $\begin{array}{l}\text { Money: No effect. Time: + from self-gain } \\
\text { appeal if the belief in karma is weak; } \\
\text { + from other-gain appeal if the belief } \\
\text { in karma is strong. }\end{array}$ & $\begin{array}{l}\text { Kulow and } \\
\text { Kramer }(2016)\end{array}$ \\
\hline Pure and impure altruism & $\begin{array}{l}\text { Money and Time: Motivation includes pure and } \\
\text { impure altruism. Time donation: } \\
\text { More + from impure altruism. }\end{array}$ & $\begin{array}{l}\text { Lilley and } \\
\text { Slonim (2014) }\end{array}$ \\
\hline Warm glow & Refer to Table 11. & $\begin{array}{l}\text { Brown, Meer } \\
\text { and Williams } \\
\text { (2019) }\end{array}$ \\
\hline
\end{tabular}

+ means "positive effect", - means "negative effect".

Source: original table based on the papers in the review sample. 
As for motivation, the marketers may use different appeals to motivate donations. Money donation may respond better to competent appeals and time donation better to warm appeals (Zhang, Lin and Yang, 2019), while money donation may respond better to egoistic appeals and time donation better to altruistic appeals (Kim, 2014).

\section{Table 6. Psychological Factors: Appeals}

\begin{tabular}{l|l|l|l}
\hline \multicolumn{1}{c|}{ Factors } & \multicolumn{1}{c|}{$\begin{array}{c}\text { Moderators/ } \\
\text { Mediators }\end{array}$} & \multicolumn{1}{c|}{$\begin{array}{c}\text { Effects on Money Donation and } \\
\text { Time Donation Intention/Behavior }\end{array}$} & References \\
\hline Advertisement appeals & $\begin{array}{l}\text { Social connectedness } \\
\text { and competitive } \\
\text { orientation }\end{array}$ & $\begin{array}{l}\text { Money: More + to competent appeals (mediation } \\
\text { of competitive orientation) Time: More + to } \\
\text { warm appeals (mediation of social connectedness) }\end{array}$ & $\begin{array}{l}\text { Zhang, Lin } \\
\text { and Yang } \\
(2019)\end{array}$ \\
\hline Advertising appeals & $\begin{array}{l}\text { Money: More + by egoistic appeals } \\
\text { or advertising showing the needy.Time: More } \\
\text { + by altruistic appeals or advertising showing } \\
\text { beneficiaries who had been helped }\end{array}$ & Kim (2014) \\
\hline
\end{tabular}

+ means "positive effect", - means "negative effect".

Source: original table based on the papers in the review sample.

A significant number of the papers in the review sample deal with temporal distance and construal level. Different constructs have different impacts on money and time donation (e.g. Karatas and Gurhan-Canli, 2020), with money especially being a more concrete construct and time a more abstract construct (MacDonnell and White, 2015). Also corresponding to construal levels are temporal distances, which may vary due to the time being near or far (Ein-Gar and Levontin, 2013) and may affect mindsets as being abstract or concrete (Bischoff and Hansen, 2016), as well as preferences between money and time donation (Madurapperuma and Kim, 2020). As a result, money and time donation may be affected by whether the temporal distance and construal level match (Song and Kim, 2019) and may impact the intention to donate in the distant versus in the near future (Bischoff and Hansen, 2016). The literature indicates that money donation is more concrete and matches with shorter temporal distance, whereas time donation is more abstract and matches with longer temporal distance (e.g. Karatas and Gurhan-Canli, 2020; Song and Kim, 2019). 


\section{Table 7. Psychological Factors: Temporal Distance and Construal Level}

\begin{tabular}{|c|c|c|c|}
\hline Factors & $\begin{array}{l}\text { Moderators/ } \\
\text { Mediators }\end{array}$ & $\begin{array}{l}\text { Effects on Money Donation and } \\
\text { Time Donation Intention/Behavior }\end{array}$ & References \\
\hline $\begin{array}{l}\text { The constructs } \\
\text { of religion (concrete) } \\
\text { and God (abstract) }\end{array}$ & $\begin{array}{l}\text { "Feeling right" under } \\
\text { construal level fit }\end{array}$ & $\begin{array}{l}\text { Money and Time: }+ \text { when the prime is God } \\
\text { (vs. religion) and the donation appeal } \\
\text { is abstract (vs concrete). }\end{array}$ & $\begin{array}{l}\text { Karatas and } \\
\text { Gurhan-Canli } \\
(2020)\end{array}$ \\
\hline $\begin{array}{l}\text { The constructs } \\
\text { of money (concrete) } \\
\text { and time (abstract) }\end{array}$ & Resource abundance & $\begin{array}{l}\text { Money and Time: + when the donation } \\
\text { appeal matches the construal level } \\
\text { (concrete for money and abstract for time) }\end{array}$ & $\begin{array}{l}\text { MacDonnell } \\
\text { and White } \\
(2015)\end{array}$ \\
\hline $\begin{array}{l}\text { Donation to } \\
\text { organization (instead } \\
\text { of a unique person) }\end{array}$ & Empathy & $\begin{array}{l}\text { Money and Time: More }+ \text { if the donors } \\
\text { are temporally or socially distant from } \\
\text { the receiver }\end{array}$ & $\begin{array}{l}\text { Ein-Gar and } \\
\text { Levontin } \\
(2013)\end{array}$ \\
\hline $\begin{array}{l}\text { Donate in the distant } \\
\text { vs. the near future }\end{array}$ & $\begin{array}{l}\text { Abstract mindset } \\
\text { induced by construal } \\
\text { level }\end{array}$ & Money and Time: + & $\begin{array}{l}\text { Bischoff and } \\
\text { Hansen (2016) }\end{array}$ \\
\hline $\begin{array}{l}\text { The match between } \\
\text { temporal distance and } \\
\text { construal level }\end{array}$ & Attitude & $\begin{array}{l}\text { Money and Time: When the donor's } \\
\text { attitude to the NPO is favorable, money } \\
\text { (low-level construal source) is preferred } \\
\text { when temporal distance is short; time } \\
\text { (high-level) when temporal distance long. } \\
\text { When attitude is not favorable, the situation } \\
\text { is mismatched (i.e. the opposite) }\end{array}$ & $\begin{array}{l}\text { Song and Kim } \\
(2019)\end{array}$ \\
\hline $\begin{array}{l}\text { Construal level and } \\
\text { personality traits }\end{array}$ & & Refer to Table 9 and Table 11. & $\begin{array}{l}\text { Madurapperuma } \\
\text { and Kim } \\
(2020)\end{array}$ \\
\hline
\end{tabular}

+ means "positive effect", - means "negative effect".

Source: original table based on the papers in the review sample.

Another notable theme of the papers in the review sample is identity, especially moral identity. The different experiments reported in those papers indicate that moral identity has a positive effect on money and time donation. Moral identity also often makes people prefer time donation to money donation (Reed, Kay, et al. 2016). Moral identity has different dimensions, e.g. moral identity symbolization and internalization (Winterich, Mittal and Aquino, 2013), where donor recognition may 
increase money and time donation among those with high moral identity symbolization and low moral identity internalization. The study by Winterich, Mittal and Aquino (2013) will also appear in Table 9 below, as it also analyzes the external factor of recognition that has effects on money and time donation. Likewise, Reed, Kay, et al. (2016) will also appear in Table 11 below, as their study also deals with preference between money and time donation.

Table 8. Psychological Factors: Identity

\begin{tabular}{l|l|l|l}
\hline \multicolumn{1}{c|}{ Factors } & \multicolumn{1}{c|}{$\begin{array}{c}\text { Moderators/ } \\
\text { Mediators }\end{array}$} & $\begin{array}{c}\text { Effects on Money Donation and } \\
\text { Time Donation Intention/Behavior }\end{array}$ & \multicolumn{1}{c}{ References } \\
\hline $\begin{array}{l}\text { Reflection on the } \\
\text { identity as } \\
\text { a benefactor rather } \\
\text { than a beneficiary }\end{array}$ & & \multicolumn{1}{c}{ (2012) } \\
\hline Moral identity & Chronic salience & $\begin{array}{l}\text { Intention and Behavior: Moral cue reduces } \\
\text { time aversion }\end{array}$ & $\begin{array}{l}\text { Reed, Kay, et al. } \\
\text { Dutton and }\end{array}$ \\
\hline Recognition & Social reinforcement & $\begin{array}{l}\text { + among consumers with high moral } \\
\text { identity symbolization and/or low moral } \\
\text { identity internalization }\end{array}$ & $\begin{array}{l}\text { Winterich, } \\
\text { Mittal and } \\
\text { Aquino (2013) }\end{array}$ \\
\hline
\end{tabular}

+ means "positive effect", - means "negative effect".

Source: original table based on the papers in the review sample.

Other experimental research regarding internal factors that may affect money and time donation are summed up in Table 9. Moral conflict (Lin and Reich, 2018), relatedness (Pavey, Greitemeyer and Sparks, 2011), mindset (Liu and Aaker, 2008), distributional preference (Nelson, Schluter and Vance, 2018) and narcissism (Konrath, Ho and Zarins, 2016) may all affect money and time donation. Moreover, Bekkers (2010) reports that material, social and psychological incentives, socio-demographic and personal characteristics may all affect money and time donation. 
Table 9. Psychological Factors: Other Internal Factors

\begin{tabular}{|c|c|c|c|}
\hline Factors & $\begin{array}{l}\text { Moderators/ } \\
\text { Mediators }\end{array}$ & $\begin{array}{l}\text { Effects on Money Donation and } \\
\text { Time Donation Intention/Behavior }\end{array}$ & References \\
\hline Relatedness & $\begin{array}{l}\text { Feeling } \\
\text { of connectedness }\end{array}$ & $\begin{array}{l}\text { Money and Time: + for highlighting } \\
\text { relatedness }\end{array}$ & $\begin{array}{l}\text { Pavey, } \\
\text { Greitemeyer } \\
\text { and Sparks } \\
(2011)\end{array}$ \\
\hline $\begin{array}{l}\text { Distributional } \\
\text { preference types }\end{array}$ & & $\begin{array}{l}\text { Money and Time: Egalitarian people were more } \\
\text { likely to donate than own-money maximizing } \\
\text { and malevolent people; benevolent people } \\
\text { donated the most among the actual donors }\end{array}$ & $\begin{array}{l}\text { Nelson, } \\
\text { Schluter and } \\
\text { Vance (2018) }\end{array}$ \\
\hline Narcissism & & $\begin{array}{l}\text { Money: - for narcissism. Time: People with } \\
\text { more narcissism do more public and emotional } \\
\text { time donation }\end{array}$ & $\begin{array}{l}\text { Konrath, Ho } \\
\text { and Zarins } \\
(2016)\end{array}$ \\
\hline Personality traits & & $\begin{array}{l}\text { People with a more independent-self: } \\
\text { Prefer money and time donation in the near } \\
\text { future People with a more interdependent-self: } \\
\text { Prefer money and time donation in the distant } \\
\text { future }\end{array}$ & $\begin{array}{l}\text { Madura- } \\
\text { pperuma } \\
\text { and Kim }(2020)\end{array}$ \\
\hline $\begin{array}{l}\text { Material, social and } \\
\text { psychological } \\
\text { incentives; socio- } \\
\text {-demographic and } \\
\text { personality } \\
\text { characteristics }\end{array}$ & & $\begin{array}{l}\text { Money and Time: + for scenario characteristics, } \\
\text { females, younger, empathy, Catholic, donation } \\
\text { in the past year and the amount donated. } \\
\text { Money: + for verbal proficiency; - for helpfulness } \\
\text { Time: + for more education, empathy, warmth, } \\
\text { extraversion, helpfulness, perspective taking, } \\
\text { blood donation in the past. - for hourly } \\
\text { wage, ownership of house, verbal proficiency. }\end{array}$ & Bekkers (2010) \\
\hline
\end{tabular}

+ means "positive effect", - means "negative effect".

Source: original table based on the papers in the review sample.

Some of the papers in the review sample used experiments to investigate other motivations for money and time donation. As external factors that may affect money and time donation, consideration has been given to recognition (Winterich, Mittal and Aquino, 2013), the existence of a choice of random outcome (Lin and Reich, 2018), hazy weather which 
raises the salience of mortality for the donor ( $\mathrm{Li}$, et al. 2020), website designs which create certain perceptions (Karatas and Gurhan-Canli, 2020), virtual reality (Kandaurova and Lee, 2019), fundraising solicitations from people who have made a time donation before (Yeomans and Al-Ubaydli, 2018) and celebrity endorsement (Wheeler, 2009), as summed up in Table 10.

Table 10. Psychological Factors: Other External Factors

\begin{tabular}{|c|c|c|c|}
\hline Factors & $\begin{array}{l}\text { Moderators/ } \\
\text { Mediators }\end{array}$ & $\begin{array}{l}\text { Effects on Money Donation and } \\
\text { Time Donation Intention/Behavior }\end{array}$ & References \\
\hline Hazy weather & Donation type & Money and Time: + & $\mathrm{Li}$, et al. (2020) \\
\hline Virtual reality & $\begin{array}{l}\text { Empathy, guilt and } \\
\text { social responsibility }\end{array}$ & Money and Time: + & $\begin{array}{l}\text { Kandaurova } \\
\text { and Lee (2019) }\end{array}$ \\
\hline Websites & & $\begin{array}{l}\text { Money and Time: + Perceptions of argument } \\
\text { strength, positive and negative affect. }\end{array}$ & $\begin{array}{l}\text { Simmons and } \\
\text { Emanuele } \\
(2004)\end{array}$ \\
\hline $\begin{array}{l}\text { Fundraising } \\
\text { solicitations }\end{array}$ & Time with the firm & $\begin{array}{l}\text { Money: + on long-time volunteers } \\
\text { Time: - on new volunteers, no difference } \\
\text { among long-time volunteers }\end{array}$ & $\begin{array}{l}\text { Yeomans and } \\
\text { Al-Ubaydli } \\
(2018)\end{array}$ \\
\hline $\begin{array}{l}\text { Connection with } \\
\text { a celebrity }\end{array}$ & Source credibility & $\begin{array}{l}\text { Money and Time: + for celebrity connection; } \\
\text { + for source credibility dimensions }\end{array}$ & Wheeler (2009) \\
\hline Recognition & Social reinforcement & $\begin{array}{l}\text { + among consumers with high moral identity } \\
\text { symbolization and low moral identity } \\
\text { internalization. }\end{array}$ & $\begin{array}{l}\text { Winterich, } \\
\text { Mittal and } \\
\text { Aquino (2013) }\end{array}$ \\
\hline $\begin{array}{l}\text { Choice of random } \\
\text { outcome }\end{array}$ & & $\begin{array}{l}\text { Some people prefer to be assigned to random } \\
\text { outcome than making their own choice about } \\
\text { money and time donation. }\end{array}$ & $\begin{array}{l}\text { Lin and Reich } \\
(2018)\end{array}$ \\
\hline
\end{tabular}

+ means "positive effect", - means "negative effect".

Source: original table based on the papers in the review sample. 


\section{Preference between Money and Time Donation}

Four of the papers in the review sample share a distinct theme: Preferences. They deal with preferences for money donation versus time donation (Brown, Meer and Williams, 2019; Reed, Kay, et al. 2016) and preferences created by the time-ask effect (Liu and Aaker, 2008). Here, time-ask means asking the respondents for time donation behavior, or for time donation intention before the money donation request; Liu and Aaker (2008) report it has a positive effect on money donation. Also note that construal level and personality traits may influence the preference for money or time donation (Madurapperuma and Kim, 2020). The study by Madurapperuma and Kim (2020) was also mentioned earlier when we discussed construal level and temporal distance. Also note that Lin and Reich (2018) also deal with preferences, albeit preferences for random choice, not preferences between money and time donation, so it is not included in Table 11 here.

\section{Table 11. Preference between Money and Time Donation}

\begin{tabular}{|c|c|c|}
\hline Factor & Preference & References \\
\hline $\begin{array}{l}\text { Warm glow } \\
\text { Moral identity } \\
\text { Time-Ask } \\
\text { Construal level }\end{array}$ & $\begin{array}{l}\text { Time }>\text { Money } \\
\text { Reduces time aversion } \\
\text { Time-Ask effect: }+ \text { on money donation } \\
\text { In the near future: Time }>\text { Money } \\
\text { In the distant future: Money }>\text { Time }\end{array}$ & $\begin{array}{l}\text { Brown, Meer and Williams (2019) } \\
\text { Reed, Kay, et al. (2016) } \\
\text { Liu and Aaker (2008) } \\
\text { Madurapperuma and Kim (2020) }\end{array}$ \\
\hline
\end{tabular}

> means "preferred to". + means "positive effect".

Source: original table based on the papers in the review sample.

\section{Complements or Substitutes}

Whether money and time donation are complements or substitutes has been a long-standing issue in the literature. In our sample of 39 papers, 2 are relevant to this topic (Yeomans and Al-Ubaydli, 2018; Lilley and Slonim, 2014). A natural field experiment found money and time donation behaviors not to be substitutes (Yeomans and Al-Ubaydli, 2018), whereas 
a lab experiment found money and time donation behaviors likely to be substitutes (Lilley and Slonim, 2014). The study by Lilley and Slonim (2014) is also mentioned in our summary of psychological factors that may bear upon money and time donation, as it investigates pure altruism and impure altruism (warm glow) as motivations of money and time donations.

\section{Philanthropy education}

6 papers out of the 39 papers in the review sample are about philanthropy education. In the conceptual structure map we may also find their topics gathered into one cluster. Those papers all make use of field experiments with actual philanthropy education programs or classes. As we may find from the table below, most of the studies found philanthropy education to exert a positive impact on both money and time donation (e.g. Benz, et al. 2020; McDougle, McDonald, et al. 2017; Olberding, 2012). However, some studies also found some different results (e.g. Green and Walkuski, 2020; Li, Xu and McDougle, 2019; Reinke, 2003).

Table 12. Effect of Philanthropy Education on Money and Time Donation

\begin{tabular}{|c|c|c|c|}
\hline & $\begin{array}{l}\text { Effect on money } \\
\text { donation }\end{array}$ & $\begin{array}{l}\text { Effect on time } \\
\text { donation }\end{array}$ & References \\
\hline $\begin{array}{l}\text { Short-Term Effect } \\
\text { on Donation Intention }\end{array}$ & $\begin{array}{l}+ \\
+ \text { in qualitative results, } \\
\text { and for social cause only } \\
\text { in quantitative results }\end{array}$ & $\begin{array}{l}\text { + } \\
+ \text { (not significant) } \\
+ \text { in qualitative results } \\
\text { and - or nonsignificant } \\
\text { in quantitative results }\end{array}$ & $\begin{array}{l}\text { Li, Xu and } \\
\text { McDougle (2019) } \\
\text { McDougle, } \\
\text { McDonald, et al. } \\
\text { (2017) } \\
\text { Benz, et al. (2020) } \\
\text { Reinke, } 2003\end{array}$ \\
\hline Long-Term Effect & $\begin{array}{l}\text { Both: + } \\
\text { Behavior: NA }\end{array}$ & $\begin{array}{l}\text { Both: }+ \\
\text { Behavior: NA }\end{array}$ & $\begin{array}{l}\text { Olberding (2012) } \\
\text { Green and Walkuski } \\
(2020)\end{array}$ \\
\hline
\end{tabular}

+ means "positive effect", - means "negative effect".

Source: original table based on the papers in the review sample. 


\section{CSR}

3 out of the 39 papers in the review sample mention how CSR (Corporate Social Responsibility) affects consumers' money and time donation (Negrao, Mantovani and de Andrade, 2018; Mantovani, de Andrade and Negrao, 2017; Romani and Grappi, 2014). In general, CSR promotes consumers' prosocial tendencies, in both intentions (Negrao, Mantovani and de Andrade, 2018; Mantovani, de Andrade and Negrao, 2017) and behavior (Romani and Grappi, 2014), while consumer-brand social distance may act as a moderator (Negrao, Mantovani and de Andrade, 2018; Mantovani, de Andrade and Negrao, 2017) and moral elevation may act as a mediator (Romani and Grappi, 2014).

\section{Table 13. The Effect of CSR on Money and Time Donation}

\begin{tabular}{l|l|l|l}
\hline \multicolumn{1}{c|}{ Moderator } & \multicolumn{1}{|c|}{ Money Donation } & \multicolumn{1}{c|}{ Time Donation } & \multicolumn{1}{c}{ References } \\
\hline $\begin{array}{l}\text { Consumer-brand } \\
\text { social distance }\end{array}$ & Behavior: + & Intention: + & $\begin{array}{l}\text { Negrao, } \\
\text { Mantovani } \\
\text { and de Andrade } \\
(2018)\end{array}$ \\
\hline & $\begin{array}{l}\text { Intention (for public-serving } \\
\text { motivation of the company): } \\
\text { +Intention (for self-serving } \\
\text { motivation of the company): }\end{array}$ & $\begin{array}{l}\text { Intention (for public-serving } \\
\text { motivation of the company): } \\
\text { +Intention (for self-serving } \\
\text { motivation of the company): }-\end{array}$ & $\begin{array}{l}\text { Mantovani, } \\
\text { de Andrade and } \\
\text { Negrao (2017) }\end{array}$ \\
\hline Mediator & Money Donation & Time Donation & $\begin{array}{l}\text { Romani and } \\
\text { Grappi (2014) }\end{array}$ \\
\hline Moral elevation & Intention and Behavior: + & Intention and Behavior: + & \\
\hline
\end{tabular}

+ means "positive effect", - means "negative effect".

Source: original table based on the papers in the review sample.

\section{Judgment of Charitable Behavior}

Two of the 39 papers in the review sample deal with how people judge charitable behaviors. For Reed, Aquino and Levy (2007), moral identity 
makes people to perceive time donation behavior as more moral and selfexpressive, and organizational status makes people to prefer to donate money. For Newman and Cain (2014), tainted altruism, which makes the donor benefit from the charitable behavior personally, may make people perceive either money donation or time donation as more negative than non-charitable behavior, while counterfactual information may act as a moderator.

\section{The Predictor of Fear Facial Expression Recognition}

Among the 39 papers in the review sample, only one focuses on prediction of prosocial behavior. Apinunmahakul and Devlin (2008) report that people who can recognize fear facial expression more accurately also make more money and time donation, and this is even a better predictor than gender, mood or scores on empathy scale. This issue is also briefly touched upon in Bekkers (2010): Certain personality characteristics and values may serve as predictors of money and time donation.

\section{Development of Scale}

Michel and Rieunier (2012) developed a scale with four dimensions (usefulness, efficiency, affect and dynamism) to measure the brand images of charity organizations, and investigated how different dimensions explain the intention to donate money and to donate time differently. They report that $31 \%$ of the intention of money donation is explained by brand image, $29 \%$ by typicality, while $24 \%$ of the intention of time donation is explained by brand image, $23 \%$ by typicality.

\section{Conclusions}

Using the snowballing technique, we iteratively identified a pool of 133 papers published in academic journals 2000-2020 dealing with both money donation and time donation. Of these, we selected all the 
experimental papers, 39 in number, as the review sample for the present study. Our examination of the 39 experimental papers in the review sample enables us to make certain generalizations about which issues are dealt with more extensively, or less so, in the existing literature, and also to posit some areas for future research.

As for the issues most broadly addressed, the vast majority (36 papers) of papers in the review sample dealt with the question of what influences money donation and time donation (e.g. Converse, Risen and Carter, 2012; Zhang, Lin and Yang, 2019; Karatas and Gurhan-Canli, 2020). Among these 36 papers, the majority (24 papers) deal with the psychological factors that affect money and time donation, which includes motivators (e.g. Kulow and Kramer, 2016; Lilley and Slonim, 2014), appeals (e.g. Kim, 2014), temporal distance and construal levels (e.g. MacDonnell and White, 2015), identity and moral identity (e.g. Reed, Kay, et al. 2016; Winterich, Mittal and Aquino, 2013), other internal factors (e.g. Nelson, Schluter and Vance, 2018; Pavey, Greitemeyer and Sparks, 2011) and other external factors (e.g. Kandaurova and Lee, 2019; Simmons and Emanuele, 2004). The remainder of the 36 papers (i.e. 12 papers) deal with preferences between time donation and money donation (e.g. Reed, Kay, et al. 2016; Liu and Aaker, 2008), whether money and time donation are complements or substitutes (e.g. Yeomans and Al-Ubaydli, 2018; Lilley and Slonim, 2014), how philanthropy education affects money and time donation (e.g. McDougle, McDonald, et al. 2017; Reinke, 2003), and how CSR affects money and time donation (e.g. Negrao, Mantovani and de Andrade, 2018; Mantovani, de Andrade and Negrao, 2017). In particular, philanthropy education and CSR are two significant factors other than psychological factors that affect money and time donation. Moreover, apart from the papers concerning the factors that influence money and time donation, a few papers deal with judgments (e.g. Newman and Cain, 2014; Reed, Aquino and Levy, 2007), predictors (e.g. Apinunmahakul and Devlin, 2008) and scale (e.g. Michel and Rieunier, 2012) of money and time donations. Most of the 39 papers analyze only intentions or behaviors of money and time donation (e.g. Karatas and Gurhan-Canli, 2020; Kulow and Kramer, 2016), with only a few considering both intentions and behaviors (e.g. Li, et al. 2020; MacDonnell and White, 2015). 


\section{Discussion and Future Research}

Some of the findings of this review study may likewise serve as a guide to identifying promising avenues for future research. The first such finding is the general dearth of research that addresses both intention and behavior of money and time donation. Often, as shown above, studies consider either intention (e.g. Madurapperuma and Kim, 2020), or behavior (e.g. Lin and Reich, 2018; Converse, Risen and Carter, 2012), while only a few deal with both (e.g. Li, et al. 2020; MacDonnell and White, 2015). In connection with this, only very few papers (e.g. Simmons and Emanuele, 2004) have aimed at discovering the differences between intention of money or time donation and behavior of money or time donation. The relationship between intention and behavior has been a difficult topic for exploration (Courneya, 1994), but it may be particularly important to differentiate them in prosocial behavior, including money and time donation - because money and time donation require people to give up some resources they own (Lin and Reich, 2018), it seems reasonable to expect to find significant discrepancies between intention and behavior here.

Reviewing the findings presented in the papers themselves, we may also notice certain fields within the study of money and time donation that may particularly benefit from more experimental research. First, there is only one paper (Apinunmahakul and Devlin, 2008) concerning the predictor(s) of money and time donation. While we may assume that motivators are sometimes good predictors (e.g. Converse, Risen and Carter, 2012), it is also important to differentiate between motivators and predictors for money and time donation, since there may be predictors that are not motivators (e.g. Apinunmahakul and Devlin, 2008). So, while there is a lot of research about motivation (e.g. Kulow and Kramer, 2016; Lilley and Slonim, 2014; Converse, Risen and Carter, 2012), studying predictors of money and time donation may be a good topic for further research. Second, even though it has been recognized that a charitable organization is different from a group of people (EinGar and Levontin, 2013), few papers focus on this, and so this may be a good topic for further research. Third, most of the experimental papers 
focus on what influences money and time donations, but very few focus on the converse, i.e. what money and time donations themselves may influence. In non-experimental work, there is research about the influences of money and time donation on consumers' physical and mental health (e.g. Choi and Kim, 2011; Qu, Konrath and Poulin, 2020), whereas in experimental research little work has been done in this direction. As such, this may work as another good topic for further research.

A final general finding is that there are some potential conflicts in the literature that need to be sorted out. For example, the studies indicate that money donation is due to pure altruism and time due to impure altruism (Lilley and Slonim, 2014), that narcissism (Konrath, Ho and Zarins, 2016) and warm glow (Brown, Meer and Williams, 2019) promote time donation more, and yet, also that money donation responds to competent appeal better and time donation to warm appeal better (Zhang, Lin and Yang, 2019). But if money donation is more purely altruistic than time donation, then why does time donation respond more to warm appeal than money donation? And why does egoistic appeal work better for money donation and altruistic appeal work better for time donation (Kim, 2014)?

Overall, our hope that this review study may serve as a useful indicator of where the experimental study of money and time donation now stands, and also as a systematic guide to where more experimental research on money and time donation may be productively focused in the future.

\section{Acknowledgement}

The author is grateful to Prof. Praggyan Mohanty for her constructive suggestions.

\section{Endnotes}

1 As papers may cover more than 1 topic, the numbers may not add up to 39 in the table. 


\section{References}

1. Apinunmahakul, A., \& Devlin, R. A. (2008). Social networks and private philanthropy. Journal of Public Economics, 92(1-2): 309-328. https://doi.org/10.1016/ j.jpubeco.2007.07.005.

2. Bauer, T. K., Bredtmann, J., \& Schmidt, C. M. (2013). Time vs. money - The supply of voluntary labor and charitable donations across Europe. European Journal of Political Economy, 32: 80-94. https://doi.org/10.1016/j.ejpoleco.2013.06.006.

3. Bekkers, R. (2010). Who gives what and when? A scenario study of intentions to give time and money. Social Science Research, 39(3): 369-381. https://doi.org/10.1016/ j.ssresearch.2009.08.008.

4. Bekkers, R, van Ingen, E, de Wit, A, \& van Groenou, M. B. (2016). Why do people volunteer? A review of the literature. Retrieved from https://osf.io/pftt3/download on 7/11/2020.

5. Bekkers, R., \& Wiepking, P (2011). Who gives? A literature review of predictors of charitable giving. Part One: Religion, education, age and socialization. Voluntary Sector Review, 2(3): 337-365.

6. Bekkers, R., \& Wiepking, P (2010). A literature review of empirical studies of philanthropy: Eight mechanisms that drive charitable giving. Nonprofit and Voluntary Sector Quarterly, 20(10): 1-50. https://doi.org/10.1177\%2F0899764010380927.

7. Benz, T. A., Piskulich, J. P., Kim, S., Barry, M., \& Havstad, J. C. (2020). Student philanthropy and community engagement: A program evaluation. Innovative Higher Education, 45(4): 17-33. https://doi.org/10.1007/s10755-019-09484-8.

8. Berger, I. E. (2006). The influence of religion on philanthropy in Canada. Voluntas, 17(2): 110-27. https://oi.org/10.1007/s11266-006-9007-3.

9. Biernacki, P. \& Waldorf, D. (1981). Snowball sampling: Problems and techniques of chain referral sampling. Sociological Methods and Research, 10(2): 141-163. https://doi.org/10.1177\%2F004912418101000205.

10. Bischoff, C., \& Hansen, J. (2016). Influencing support of charitable objectives in the near and distant future: Delay discounting and the moderating influence of construal level. Social Influence, 11(4): 217-229. https://doi.org/10.1080/15534510.2016.1232204.

11. Borgonovi, F. (2008). Divided we stand, united we fall: Religious pluralism, giving, and volunteering. American Sociological Review, 73(1): 105-128. https://doi.org/10.1177\%2F000312240807300106.

12. Brown, A. L., Meer, J., \& Williams, J. F. (2019). Why do people volunteer? An experimental analysis of preferences for time donations. Management Science, 65(4): 1455-1468. https://doi.org/10.1287/mnsc.2017.2951.

13. Browne, K. (2005). Snowball sampling: Using social networks to research nonheterosexual women. International Journal of Social Research Methodology, 8(1): 47-60. https://doi.org/10.1080/1364557032000081663.

14. Choi, N. G. and Chou, R. Jing-Ann (2010). Time and money volunteering among older adults: The relationship between past and current volunteering and correlates of change and stability. Ageing \& Society, 30(4): 559-581. https://psycnet.apa.org/doi/10.1017/S0144686X0999064X. 
15. Choi, N, \& Kim, J. (2011). The effect of time volunteering and charitable donations in later life on psychological wellbeing. Ageing \& Society, 31(4): 590-610. https://psycnet.apa.org/doi/10.1017/S0144686X10001224.

16. Choi, N.G., \& DiNitto, D. M. (2012). Predictors of time volunteering, religious giving, and secular giving: Implications for nonprofit organizations. Journal of Sociology and Social Welfare, 39(2): 93-120.

17. Converse, B. A., Risen, J. L., \& Carter, T.J. (2012). Investing in karma: When wanting promotes helping. Psychological Science, 23(8): 923-930. https://doi.org/10.1177\%2F0956797612437248.

18. Courneya, K. S. (1994). Predicting repeated behavior from intention: The issue of scale correspondence. Journal of Applied Social Psychology, 24(7): 580-594. https://psycnet.apa.org/doi/10.1111/j.1559-1816.1994.tb00601.x.

19. Devlin, R. A., \& Zhao, W. Z. (2017). Are Quebeckers really stingier than other Canadians? An empirical analysis of philanthropy in Canada and how Quebec compares to other provinces. Canadian Journal of Nonprofit and Social Economy Research, 8(1): 20-39.

20. Diop, A, Johnston, T, Le, K. T., \& Li, Y. J. (2018). Donating time or money? The effects of religiosity and social capital on civic engagement in Qatar. Social Indicators Research, 138(1): 297-315. https://doi.org/10.1007/s11205-017-1646-9.

21. Ein-Gar, D., \& Levontin, L. (2013). Giving from a distance: Putting the charitable organization at the center of the donation appeal. Journal of Consumer Psychology, 23(2): 197-211. https://doi.org/10.1016/j.jcps.2012.09.002.

22. Faulkner, M., \& Romaniuk, J. (2019). Supporters' perceptions of benefits delivered by different charity activities. Journal of Nonprofit \& Public Sector Marketing, 32(1): 20-41. https://doi.org/10.1080/10495142.2018.1452829.

23. Feeley, T. H., Anker, A. E., \& Aloe, A. M. (2012). The door-in-the-face persuasive message strategy: A meta-analysis of the first 35 years. Communication Monographs, 79(3): 316-343. https://doi.org/10.1080/03637751.2012.697631.

24. Feldman, N. E. (2010). Time is money: Choosing between charitable activities. American Economic Journal-Economic Policy, 2(1): 103-130. https:/www.jstor.org/ stable/25760053.

25. Forbes, K. F., \& Zampelli, E. M. (2011). An assessment of alternative structural models of philanthropic behavior. Nonprofit and Voluntary Sector Quarterly, 40(6): 1148-1167. https://doi.org/10.1177\%2F0899764010379054.

26. Gertler, A. (2015). Charitable fundraising and smart giving: How can charities use behavioral science to drive donations? Retrieved from https://aarongertler.net/wpcontent/uploads/2018/01/Aaron-Gertler-Senior-Thesis-full-bibliography-1.pdf on $7 / 8 / 2020$.

27. Goktas, V., Erol, E., Altunisik, R., \& Ardic, K. (2019). Social marketing in charitable giving intentions: A serial mediation model. Marketing and Management of Innovations, 2019(2): 21-32. http://doi.org/10.21272/mmi.2019.2-02.

28. Grant, A., \& Dutton, J. (2012). Beneficiary or benefactor: Are people more prosocial when they reflect on receiving or giving? Psychological Science, 23(9): 1033-1039. https://doi.org/10.1177\%2F0956797612439424. 
29. Green, L., \& Walkuski, C. B.(2020). Paying it forward: Does teaching philanthropy change behavior after graduation? Journal of Nonprofit Education and Leadership, 19(2): 179-200. https://doi.org/10.18666/JNEL-2020-V10-I2-10086.

30. Handy, F., \& Katz, E. (2008). Donating behavior: If time is money, which to give? A preliminary analysis. Journal of Economic Studies, 35(4): 323 - 332.

31. Hill, M. (2012). The relationship between volunteering and charitable giving: Review of evidence. Retrieved from https://www.cass.city.ac.uk/_data/assets/pdf_file 0008/366983/wp-volunteering-and-charitable-giving-mh.pdf on 7/11/2020.

32. Jones, K. S. (2006). Giving and volunteering as distinct forms of civic engagement: The role of community integration and personal resources in formal helping. Nonprofit and Voluntary Sector Quarterly, 35(2): 249-266. https://doi.org/10.1177\% 2F0899764006287464.

33. Kandaurova, M., \& Lee, S. H. (2019). The effects of Virtual Reality (VR) on charitable giving: The role of empathy, guilt, responsibility, and social exclusion. Journal of Business Research, 100: 571-580. https://doi.org/10.1016/j.jbusres.2018.10.027.

34. Karatas, M., \& Gurhan-Canli, Z. (2020). A construal level account of the impact of religion and God on prosociality. Personality and Social Psychology Bulletin, 46(7): 1107-1120. Advanced Online Publication. https://doi.org/10.1177\% 2F0146167219895145.

35. Kim, N. (2014). Advertising strategies for charities promoting consumers' donation of time versus money. International Journal of Advertising, 33(4); 707-724. https://doi.org/10.2501/IJA-33-4-707-724.

36. Klein, N. (2017). Prosocial behavior increases perceptions of meaning in life. Journal of Positive Psychology, 12(4): 354-361. https://psycnet.apa.org/doi/10.1080/17439760. 2016.1209541.

37. Konrath, S., Ho, M. H., \& Zarins, S. (2016). The strategic helper: Narcissism and prosocial motives and behaviors. Current Psychology, 35: 182-194. https:/doi.org/ 10.1007/s12144-016-9417-3.

38. Kou, X., Konrath, S., \& Goldstein, T. R. (2019). The relationship among different types of arts engagement, empathy, and prosocial behavior. Psychology of Aesthetics, Creativity, and the Arts, 14(4): 481-492. Advance Online Publication. https://psycnet.apa.org/doi/10.1037/aca0000269.

39. Kulow, K., \& Kramer, T. (2016). In pursuit of good karma: When charitable appeals to do right go wrong. Journal of Consumer Research, 43(2): 334-353. https://doi.org/10.1093/jcr/ucw018.

40. Li, H, Xu, C., \& McDougle, L. M. (2019). Philanthropy can be learned: A qualitative study of student experiences in experiential philanthropy courses. Philanthropy \& Education, 2(2): 29-52. https://doi.org/10.2979/phileduc.2.2.02.

41. Lilley, A., \& Slonim, R. (2014). The price of warm glow. Journal of Public Economics, 114: 58-74. https://doi.org/10.1016/j.jpubeco.2013.12.004.

42. Lin, S. C., \& Reich, T. (2018). To give or not to give? Choosing chance under moral conflict. Journal of Consumer Psychology, 28(2): 211-233. https://psycnet.apa. org/doi/10.1002/jcpy.1008. 
43. Liu, W., \& Aaker, J. (2008). The happiness of giving: The time-ask effect. Journal of Consumer Research, 35(3): 543-557. https://doi.org/10.1086/588699.

44. Li, S., Fu, G., Yuan, J., \& Wu, J. (2020). Silver lining of haze: The mixed effect of haze on donation. Frontiers in Psychology, 11: 2042. https://dx.doi.org/10.3389\% 2Ffpsyg.2020.02042.

45. Lyons, M., McGregor-Lowndes, M., \& O'Donoghue, P. (2006). Researching, giving and volunteering in Australia. Australian Journal of Social Issues, 41(4): 385-397. https://doi.org/10.1002/j.1839-4655.2006.tb00995.x.

46. MacDonnell, R., \& White, K. (2015). How construals of money versus time impact consumer charitable giving. Journal of Consumer Research, 42(4): 551-563. https://doi.org/10.1093/jcr/ucv042.

47. Madurapperuma, MAYD, \& Kim, K. M. (2020). Sustaining business: A psychological perspective of donation behavior. Sustainability, 12(22): 9355. https://doi.org/ $10.3390 / \mathrm{su} 12229355$.

48. Mantovani, D., de Andrade, L. M., \& Negrao, A. (2017). How motivations for CSR and consumer-brand social distance influence consumers to adopt pro-social behavior. Journal of Retailing and Consumer Services, 36: 156-163. https:/doi.org/10.1016/ j.jretconser.2017.01.009.

49. Marsh, A. A., Kozak, M. N., \& Ambady, N. (2007). Accurate identification of fear facial expressions predicts prosocial behavior. Emotion, 7(2): 239-251. https:/dx.doi.org/ 10.1037\%2F1528-3542.7.2.239.

50. Marti-Vilar, M., Serano-Pastor, L., \& Sala, F. G. (2019). Emotional, cultural and cognitive variables of prosocial behavior. Current Psychology, 38: 912-919. https://doi.org/10.1007/s12144-019-0168-9.

51. Mason, D. P. (2013). Putting charity to the test: A case for field experiments on giving time and money in the nonprofit sector. Nonprofit and Voluntary Sector Quarterly, 42(1): 193-202. https://doi.org/10.1177\%2F0899764012449518.

52. McDougle, L., McDonald, D., Li, H., McIntyre Miller, W., \& Xu, C. (2017). Can philanthropy be taught? Nonprofit and Voluntary Sector Quarterly, 46(2): 330-351. https://doi.org/10.1177\%2F0899764016662355.

53. Michel, G., \& Rieunier, S. (2012). Nonprofit brand image and typicality influences on charitable giving. Journal of Business Research, 65(5): 701-707. https://doi.org/ 10.1016/j.jbusres.2011.04.002.

54. Monga, A., \& Zor, O. (2019). Time versus money. Current Opinion in Psychology, 26: 28-31. https://doi.org/10.1016/j.copsyc.2018.04.011.

55. Mantovani, D., \& de Andrade, L. M. (2018). Brand's CSR influence on consumers' prosocial behavior in unrelated domains. Brazilian Journal of Marketing, 17(1): 139-149. https://doi.org/10.5585/remark.v17i1.3707. 
56. Nelson, K. M., Schluter, A., \& Vance, C. (2018). Distributional preferences and donation behavior among marine resource users in Wakatobi, Indonesia. Ocean \& Coastal Management, 162: 34-45. https://doi.org/10.1016/j.ocecoaman.2017.09.003.

57. Newman, G. E., \& Cain, D. M. (2014). Tainted altruism: When doing some good is evaluated as.worse than doing no good at all. Psychological Science, 25(3): 648-655. https://doi.org/10.1177/0956797613504785.

58. Olberding, J. C. (2012). Does student philanthropy work? A study of long-term effects of the 'learning by giving' approach. Innovative Higher Education, 37(2): 71-87. https://doi.org/10.1007/s10755-011-9189-5.

59. Ottoni-Wilhelm, M., Estell, D. B., \& Perdue, N. H. (2014). Role-modeling and conversations about giving in the socialization of adolescent charitable giving and volunteering. Journal of Adolescence, 37(1): 53-66. https://doi.org/10.1016/ j.adolescence.2013.10.010.

60. Pavey, L., Greitemeyer, T., \& Sparks, P. (2011). Highlighting relatedness promotes prosocial motives and behavior. Personality and Social Psychology Bulletin, 37(7): 905-917. https://doi.org/10.1177\%2F0146167211405994.

61. Qu, H., Konrath, S., an\& Poulin, M. (2020). Which types of giving are associated with reduced mortality risk among older adults? Personality and Individual Differences, 154: 1-6. https://doi.org/10.1016/j.paid.2019.109668.

62. Reed, A., Kay, A., Finnel, S., Aquino, K., \& Levy, E. (2016). I don't want the money, I just want your time: How moral identity overcomes the aversion to giving time to prosocial causes. Journal of Personality and Social Psychology, 110(3): 435-457. https://psycnet.apa.org/doi/10.1037/pspp0000058.

63. Reed, A., Aquino, K., \& Levy, E. (2007). Moral identity and judgments of charitable behaviors. Journal of Marketing, 71(1): 178-193. https://doi.org/10.1509\% 2Fjmkg.71.1.178.

64. Reinke, S. J. (2003). Making a difference: Does service-learning promote civic engagement in MPA students? Journal of Public Affairs Education, 9, 129-137. https://doi.org/10.1080/15236803.2003.12023582.

65. Roetzel, P. G. (2019). Information overload in the information age: A review of the literature from business administration, business psychology, and related disciplines with a bibliometric approach and framework development. Business Research, 12: 479-522. https://doi.org/10.1007/s40685-018-0069-z.

66. Romani, S., \& Grappi, S. (2014). How companies' good deeds encourage consumers to adopt pro-social behavior. European Journal of Marketing, 48(5-6): 943-963. https://psycnet.apa.org/doi/10.1108/EJM-06-2012-0364.

67. Schaltegger, S., Gibassier, D., \& Zvezdov, D. (2013). Is environmental management accounting a discipline? A bibliometric literature review. Meditari Accountancy Research, 21(1): 4-31. https://doi.org/10.1108/MEDAR-12-2012-0039. 
68. Simmons, W. O., \& Emanuele, R. (2004). Does government spending crowd out donations of time and money? Public Finance Review, 32(5): 498-511. https://doi.org/10.1177\%2F1091142104264364.

69. Slattery, P., Vidgen, R., \& Finnegan, P. (2020). Winning heads and hearts? How websites encourage prosocial behavior. Behaviour \& Information Technology, 40(9): 933-961. Advance Online Publication. DOI: 10.1080/0144929X.2020.1736156.

70. Smith, W., \& Chang, C. (2002). Shipping the good apples out: A note on contributions of time and money. Economics Bulletin, 10(1): 1-14.

71. Song, D., \& Kim, D. H. (2019). I'll donate money today and time tomorrow: The moderating role of attitude toward nonprofit organizations on donation intention. International Journal of Nonprofit and Voluntary Sector Marketing. Advanced Online Publication. https://doi.org/10.1002/nvsm.1659.

72. Studte, S., Clement, M., Soliman, M., \& Boenigk, S. (2019). Blood donors and their changing engagement in other prosocial behaviors. Transfusion, 59(3): 1002-1015.

73. Sun, X., Tang, W., Ye, T., Zhang, Y., Wen, B., \& Zhang, L. (2014). Integrated care: A comprehensive bibliometric analysis and literature review. International Journal of Integrated Care, 14: e017.

74. Tiltay, M. A., \& Torlak, O. (2020). Similarities and differences of motivations of giving time and money: Giving to individuals versus humanitarian organizations in an emerging market. International Journal of Nonprofit and Voluntary Sector Marketing, 25(1): e1649. https://doi.org/10.1002/nvsm.1649.

75. Wheeler, R. T. (2009). Nonprofit advertising: Impact of celebrity connection, involvement, and gender on source credibility and intention to volunteer time or donate money. Journal of Nonprofit and Public Sector Marketing, 21: 80-107. https://doi.org/10.1080/10495140802111984.

76. Wiepking, P., \& Bekkers, R. (2012). Who gives? Who gives? A literature review of predictors of charitable giving. Part Two: Gender, family composition and income.

Voluntary Sector Review, 3(2): 217-245. https://doi.org/10.1332/ 204080512 X649379.

77. Winterich, K. P., Mittal, V., \& Aquino, K. (2013). When does recognition increase charitable behavior? Toward a moral identity-based model. Journal of Marketing, 77(3): 121-134. https://doi.org/10.1509\%2Fjm.11.0477.

78. Wohlin, C. (2014). Guidelines for snowballing in systematic literature studies and a replication in software engineering. EASE'14: Proceedings of the 18th International Conference on Evaluation and Assessment in Software Engineering, Article No. 38: 1-10. https://doi.org/10.1145/2601248.2601268.

79. Wong, K., Ong, P., \& Zheng, W. (2017). American philanthropy literature review. Retrieved from https:/faculty.sites.uci.edu/karnawong/files/2017/10/AmericanPhilanthropy-Literature-Review.pdf on 7/11/2020. 
80. Yeomans, M., \& Al-Ubaydli, O. (2018). How does fundraising affect volunteering? Evidence from a natural field experiment. Journal of Economic Psychology, 64: 57-72. DOI: 10.1016/j.joep.2017.11.004.

81. Zhang, Y., Lin, C. L. and Yang, J. L. (2019). Time or money? The influence of warm and competent appeals on donation intentions. Sustainability, 11(22): 6228. https://doi.org/10.3390/su11226228.

82. Zupic, I., \& Cater, T. (2015). Bibliometric methods in management and organization. Organizational Research Methods, 18(3): 429-472. https://doi.org/10.1177\% 2F1094428114562629.

Tingting He - Assistant Professor of Marketing at Governors State University in Illinois, United States. She holds a PhD in Marketing from Washington University in St Louis and MPhil in Marketing from the University of Manchester (known as UMIST when attended). She focuses on both quantitative modeling research and consumer behavioral research in marketing and has previously published in various journals. 